\title{
Erratum to: Religious Attendance, Stress, and Happiness in South Korea: Do Gender and Religious Affiliation Matter?
}

\author{
Jong Hyun Jung
}

Published online: 13 November 2013

(C) Springer Science+Business Media Dordrecht 2013

\section{Erratum to: Soc Indic Res \\ DOI 10.1007/s11205-013-0459-8}

After the article has been published online first, the author discovered a big typo in the abstract of the paper. The regression analyses used in the paper should read: "ordinary least squares regression analyses", not "ordinal" least square regression analyses as is shown in the abstract. The author apologizes to readers for the confusion the typo may make.

The online version of the original article can be found under doi:10.1007/s11205-013-0459-8.

J. H. Jung $(\bowtie)$

Department of Sociology, Purdue University, 700 W. State St, West Lafayette, IN 47907, USA e-mail: sociocus75@gmail.com 